\title{
Comparative Analysis on the Nutrient Quality of Undried, Freeze-Dried and Oven-Dried Fruits of Lycopersicon Esculentum Mill (Tomato)
}

\author{
William Odoom Ryan Kusi Osei-Asibey Regina Ofori Asante Yaw Gyau Akyereko \\ Department of Food and Postharvest Technology, Koforidua Technical University, P. O. Box KF 981, Koforidua, \\ Ghana
}

\begin{abstract}
Tomato (Lycopersicon esculentum mill) is a popular vegetable across the world. However, high volumes of tomato go waste every year, due to its high seasonality and perishability, especially in sub-Saharan African countries such as Ghana. This research focused on the impact of oven and freeze drying technologies on the proximate, physicochemical and antioxidant composition of freshly harvested tomatoes. Results from all samples (oven dried, freeze dried and fresh tomatoes) were analyzed by one-way ANOVA using Graph Pad prism version 5 software. There was a significant difference between the sample treatments (oven dried, fresh tomatoes and freeze dried) with respect to the $\mathrm{pH}$ ranging $3.92 \pm 0.02,4.20 \pm 0.02$ and $4.54 \pm 0.02$. The Total Soluble Solids (T.S.S) varied significantly from each other $(p<0.05)$ with the highest being $2.31 \pm 0.01^{\circ}$ brix for oven dried sample (O) and lowest for the control sample (C) with $1.20 \pm 0.00$ brix respectively. For the crude fat, there was a significant $(\mathrm{p} \leq 0.05)$ difference between the two dried samples and the control. The study also revealed that there was a significant difference in ash content between the freeze-dried sample $(1.50 \pm 0.01)$ and the other two (control $0.50 \pm 0.01 \%$, oven dried $(0.52 \pm 0.02 \%)$ samples. For the crude fiber, there was no significant difference $(p>0.05)$ between the samples. There was a significant difference $(p \leq 0.05)$ between all samples with respect to the crude protein content with values ranging from $2.40 \pm 0.01,2.71 \pm 0.01 \%$ and $4.07 \pm 0.06 \%$ for oven-dried, control and the freeze- dried treatment respectively. There was a significant difference among the various samples for vitamin $\mathrm{C}$ content. The vitamin $\mathrm{C}$ content for the control, oven dried and freeze-dried samples were $28.00 \pm 0.01 \mathrm{mg} / 100 \mathrm{~g} ; 19.40 \pm 0.01 \mathrm{mg} / 100 \mathrm{~g} ; 22.80 \pm 0.05 \mathrm{mg} / 100 \mathrm{~g}$ respectively. This shows that, though both oven and freeze-drying methods lower the vitamin $\mathrm{C}$ content of tomatoes, they are also able to preserve and add value to tomato by improving other quality parameters. It is recommended that governments invest into scientific researches of producing tomato products, which have longer shelf -life to reduce the cost of importations of tomato and tomato postharvest losses.
\end{abstract}

Keywords: Tomato, Freeze-drying, Vitamin C, Proximate analysis, Oven drying

DOI: $10.7176 / \mathrm{FSQM} / 111-04$

Publication date:October $31^{\text {st }} 2021$

\subsection{Introduction}

Tomato (Lycopersicon esculentum Mill), belonging to the family of the Solanaceae, is one of the most significant vegetables in the world (Norman, 1992; Naika et al., 2005; Peralta and Spooner, 2007). This warm season, annual, herbaceous crop (Morgan and Lennard, 2000) was introduced to West Africa by the Portuguese in the $16^{\text {th }}$ and $17^{\text {th }}$ centuries (Norman, 1992). Currently, an estimated 129 million tons of tomatoes are produced worldwide each year (FAO, 2010). Out of this, Ghana produces around 256,000 MT, and spends GH $\mathbb{C} 1.4$ million to import an additional 90,000 tons of tomato paste yearly (MOFA, 2019). In Ghana, about 90,000 farmers and an additional 300,000 retailers and wholesalers are involved in tomato production and trade (FAO, 2001; MOFA, 2013). Tomato is an important constituent of Ghanaian meals (Ellis et al., 1998) and its consumed either fresh, cooked or technologically processed as paste, puree, and juices (Brasseaux et al., 2014).

Freshly harvested tomatoes have a high moisture content above 95\%, which together with its soft outer covering makes it prone to early microbial infection and spoilage (Rati, 2001). Aside from this, poor harvesting and storage practices also contribute to its short shelf life leading to high annual post-harvest losses (PHL) of about $20-50 \%$ (Kader, 1992). This notwithstanding, tomato, being a rich source of both antioxidant vitamins (vitamin A, C, and E), and non-nutritional antioxidants (lycopene and other flavonoids, polyphenols, and phenolic acids) (Slimestand and Verheul, 2009; Veillet et al., 2009), is being utilized in greater quantities in recent times. This is due to an increase in consumer interest in consumption of functional foods. Tomato is considered a functional food, due to the association of its intake with decrease in incidence of cardiovascular disorders and certain cancers (Wang et al., 2000). Hence, further increasing the deficit in tomato supply in Ghana. As a measure of curbing the shortages in supply, the government of Ghana imports several tons of fresh tomatoes from neighboring countries to supplement our local stocks. Aside from this, local food processors, market women, and smallholders in their bid to contribute to reversing this trend either mill, can, or dry their fresh produce as a means of improving its shelf stability for the local market (Owureku-Asare et al., 2017). 
Drying is a simple technology which various actors in the tomato supply chain can easily adapt with minimal cost investment. Aside from this, it is a highly effective means of preservation to reduce postharvest losses as well as offset shortages in the supply of tomatoes year-round. Tomatoes have been commonly dried using various dehydration methods such as sun and solar drying, spray drying, oven drying, infrared radiation heating, and freeze-drying (Bashir et al., 2014). However, the choice of a drying technology depends on its efficiency, in terms of energy consumption, final food quality, and cost involvement (Ertekin and Yaldiz, 2004).

According to Owureku-Asare et al., (2017), the theory of tomatoes drying, though, not as common as using fresh or canned tomatoes, is not entirely novel among food processors and consumers in Ghana. In Northern Ghana, some farmers sun-dry tomatoes for household consumption and also for commercial purposes when patronage and sales of fresh tomatoes are low. In addition, in the Greater Accra region, milled annatto seeds, corn, and cola nuts sold as "tomato powder" were greatly patronized by cottage food processors (Owureku-Asare, et al., 2017). Therefore, consumers may readily patronize manufacturing dried tomato products on a commercial scale, particularly during its off-seasons. However, any such product must meet consumer desires for affordability as well as sensory and nutritional qualities (Ertekin and Yaldiz, 2004).

Traditional sun drying, though very cost-effective, is a slow process as compared with other drying methods (Durance and Wang, 2002). When sun-dried, there are substantial-quality losses such as lowered flavour intensity, enzymatic browning, and microbial spoilage (Okos et al., 1992; Rati, 2001). Therefore, to improve the quality of dried tomato products, industrial drying methods such as oven and freeze-drying methods are desired. Since these drying methods are more hygienic, better at maintaining product quality, and ensures minimal product loss (Corzo et al., 2008). This study, therefore, seeks to identify the effects of the oven and freeze-drying methods on the proximate, physicochemical composition, and antioxidant values of tomatoes in Ghana.

\subsection{Materials and Methods \\ 2.1 Sample Preparation}

The study was conducted from November 2019 to August 2020 at the Chemistry Laboratory of Food and Postharvest Department, Koforidua Technical University in the Eastern Region of Ghana. A 3 x 3 factorial experiment layout in a complete randomized design was adopted. The tomato fruits were purchased from the Koforidua Central Market based on size, colour and firmness (Owusu John et al., 2012) and transported in Ziploc bags. It was sorted to remove bruised ones, and then washed using chlorinated water to remove dirt, pesticide residues, diseased spores and air-dried under room conditions; the sample was very carefully selected based on a visual assessment of uniformity of ripeness, colour, size and firmness. The cleaned and air-dried tomato fruit samples were divided into 3 lots. The first was dried under room temperature condition, the next using freeze-drying method and last lot were oven-dried. All observations were replicated three times.

Table 1: Description of Materials, Treatments and Methods

\begin{tabular}{ll}
\hline Treatments & Methods \\
\hline $\mathrm{C}$ & Control sample (Air drying method was applied) \\
$\mathrm{O}$ & Oven-Drying method \\
$\mathrm{F}$ & Freeze-Drying method \\
\hline
\end{tabular}

\subsubsection{Drying Procedure}

\subsubsection{Oven Drying Method}

After immersing the tomato sample in a chlorinated water for 10 minutes, 10 of the tomato samples were chopped and weighed with an electronic balance and data taken to be $10.230 \mathrm{Kg}$. The weighed tomato sample was transferred into the laboratory tray then into the Oven Dryer (ISOTHERM $®$ ) and the temperature set to $140^{\circ}$ $\mathrm{C}$ for 24 hours until the tomato was completely dried. The tomato sample was then transferred to a laboratory blender for blending using a pause blending method to generate heat in the blender until it reached a powder form. The blended-powdered tomato sample is then poured into a Ziploc bag and sealed and labelled Oven dried Powder tomato sample with initial and final date and time respectively.
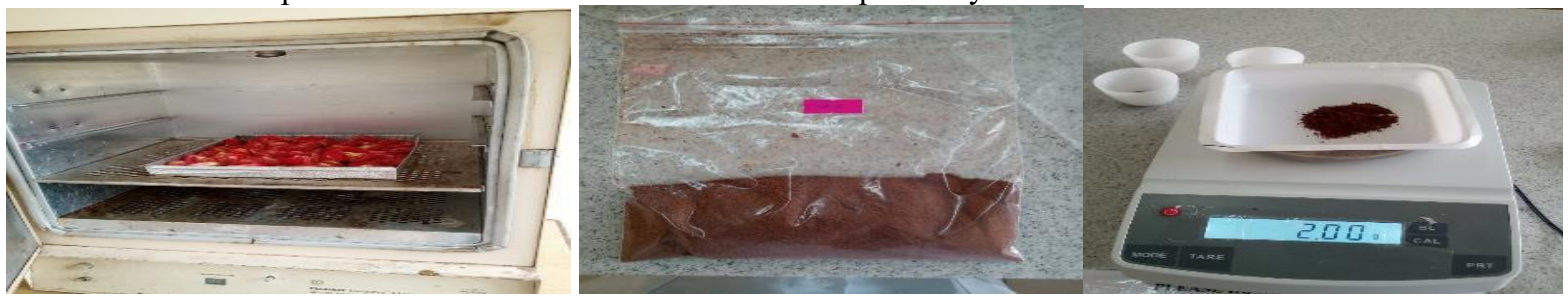

Plate 1: Various stages of oven drying from the drying in the oven to powdering stage.

\subsubsection{Freeze Drying Method}

After immersing the tomato sample in a chlorinated water for 10 minutes, 10 of the tomato samples were chopped and weighed with a top pan balance and data taken to be $10.23 \mathrm{Kg}$. The weighed tomato sample was 
transferred into a prepared 3 different round bottom flask and corked. It was then transferred into a freezer under a temperature set to $-3{ }^{\circ} \mathrm{C}$ for 4 hours until it was well frozen. The frozen tomato sample was then transferred into the Freeze Dryer (LABCONCO ${ }^{\circledR}$ ) and allowed to dry for 72 hours until the tomato sample was well dried. The sample was then transferred to a laboratory blender for blending using a pause blending method to generate heat in the blender until it reached a powder form. The blended-powdered tomato sample was then poured into a Ziploc bag, sealed and labelled Freeze Dried Powder tomato sample with initial and final date and time respectively written on it.

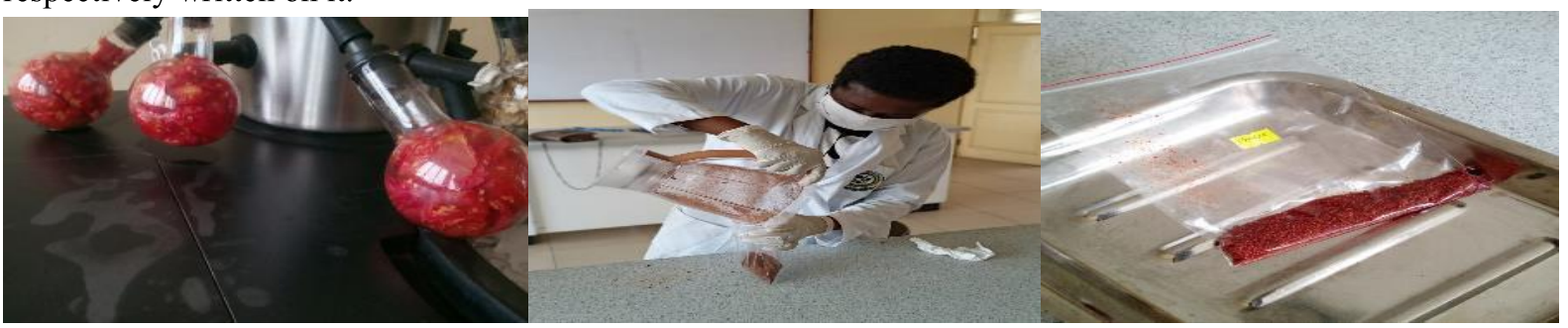

Plate 2: Various stages during the freeze drying.

\subsubsection{Air Drying under Room Temperature Method}

After immersing the tomato sample in a chlorinated water for 10 minutes, 10 of the tomato samples were chopped and weighed with a top pan balance and data taken to be $10.23 \mathrm{Kg}$. The weighed tomato sample was transferred into the laboratory tray and then spread evenly in the laboratory for 5 days until it was air-dried. The tomato sample was then transferred to a laboratory blender for blending using a pause blending method. The blended tomato sample was then poured into a Ziploc bag, sealed, and labelled Air Dried Powder Tomato sample with initial and final date and time respectively written on it. (Anonymous 2019).

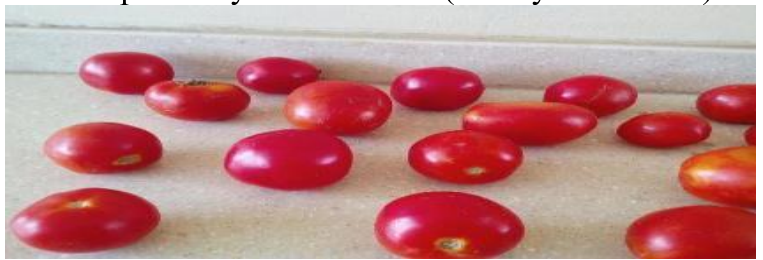

Plate 3: Fresh Tomato Fruits subjected to Air-drying

\subsubsection{Proximate Analysis}

\subsubsection{Moisture Content Determination}

The Association of Official Analytical chemist (AOAC, 2004) was used to calculate the level of moisture. Two grams $(2 \mathrm{~g})$ of the air dried, freeze dried and oven dried samples were accurately weighed using an electronic analytical balance (SARTOROUS B1205, Germany). The weight of a petri dish was tarred and each sample accurately determined and recorded. The individual samples in the petri dish were placed in an Oven dryer (FISHER ISOTEMP ${ }^{\circledR}$, Senior Model) at $105{ }^{\circ} \mathrm{C}$ for 3 hours and then the individual differences were taken using the formula. Performing in triplicates.

$\%$ Moisture $=\frac{W 1-W 2}{W 1} \times 100$

Where:

W $1=$ Weight $(\mathrm{g})$ of tomato sample + the crucible before it was dried.

$\mathrm{W} 2=$ Weight $(\mathrm{g})$ of tomato sample + the crucible after drying.

\subsubsection{Crude Protein Determination}

The Association of Official Analytical chemist (AOAC, 2004) method was used. One gram (1 g) of each of the samples was weighed using (SARTORIOUS B1205, GERMANY) and placed in a digestion flask. $25 \mathrm{ml}$ of concentrated $\mathrm{H}_{2} \mathrm{SO}_{4}$ and Kjeldahl catalyst were added. Digestion was carried out in a digestion chamber until a clear solution was obtained. The digested sample was filtered into a $100 \mathrm{ml}$ volumetric flask and made to the mark with $80 \mathrm{ml}$ distilled water and mixed well. $70 \mathrm{ml}$ of $\mathrm{NaOH}$ and $10 \mathrm{ml}$ of sample were put into Kjeldahl apparatus and heated for the distillation of ammonia. $25 \mathrm{ml}$ of $4 \%$ boric acid was measured into a conical flask to receive the liberated ammonia gas. The nitrogen content was estimated by titrating the ammonia borate formed with standard $0.096 \mathrm{~N} \mathrm{HCl}$ using mixed indicator and the titre values were recorded. The appropriate formula was used to calculate the protein content. The procedure was repeated 3 times.

$\%$ Protein $=\frac{(A-B) \times 4.007 \times 6.25}{W} \times 100$

Where:

$\mathrm{A}=$ Volume $(\mathrm{ml})$ of $0.2 \mathrm{~N} \mathrm{HCl}$ used sample titration

$\mathrm{B}=$ Volume $(\mathrm{ml})$ of the $0.2 \mathrm{~N} \mathrm{HCl}$ used sample titration 
$\mathrm{N}=$ Normality of the $\mathrm{HCl}$

$\mathrm{W}=$ Weight $(\mathrm{g})$ of sample

$14.007=$ Atomic weight of nitrogen

$6.25=$ The protein-nitrogen conversion factor.

\subsubsection{Crude Fat Determination}

The Association of Official Analytical Chemist was used to determine the crude fat content (AOAC, 2004). 2 grams of each of the samples were weighed. Empty beakers were weighed using (SARTORIOUS B1205, GERMANY). The weighed samples were transferred into thimbles and placed in a holding chamber of a (GOLDFISH APPARATUS). A $25 \mathrm{ml}$ of a petroleum ether was poured into each of the beakers. A (ASBESTOS) cotton wool was used to cover each of the thimbles. The beakers containing each of the solvents was then inserted in the gaskets of the apparatus condenser. The tap was then opened to allow free flow of water through to facilitate the condensing of the solvents. The apparatus was switched on and the sample was extracted for 4 hours within a rate of 5 drops per seconds. The beakers and their content were then oven dried using (FISHER ISOTHEMP OVEN, SENIOR MODEL) for 30 minutes and weighed on a (SARTORIUS B1205, GERMANY) to determine the difference in weight of the flask. The appropriate formula was used to calculate the fat content as follows:

$\%$ Crude Fat $=\frac{W 1}{W 2} \times 100$

Where;

$\mathrm{W} 1=$ Weight of fat

W2 $=$ Weight of sample

\subsubsection{Ashing}

The Association of Official Analytical Chemist (AOAC, 2004) was used to determine the ash content. $1 \mathrm{~g}$ of each of the samples were initially weighed using a (SARTORIOUS B1205, GERMANY) electronic analytical balance. The weight of the crucible without the sample content was determined and recorded. Each of the weighted samples were then transferred into the weighted crucibles, it was then weighed and recorded. The crucibles and its content were placed in a (THERMO SCIENTIFIC) muffle furnace at a temperature of $600{ }^{\circ} \mathrm{C}$ for (6) hrs. The hot crucibles were removed from the muffle furnace and allowed to cool in a desiccator before it was weighed and recorded. The appropriate formula was then used to determine the Ash.

$\%$ Ash $=\frac{W 3-W 1}{W 2-W 1} \times 100$

Where: W 1 = Weight of porcelain crucible,

W 2 = Weight of porcelain crucible + slices,

W 3 = Weight of porcelain crucible + Ash.

\subsubsection{Total Carbohydrate Analysis}

The total carbohydrate was determined by subtracting the percentages of moisture content, protein, fat and ash from 100 to give the percentage of carbohydrate "by difference"; according to (AOAC, 2004).

\subsubsection{Determination of Energy}

Energy content was calculated by factorial method of (AOAC, 2004).

$$
\text { Energy }(k / \text { cal })=(4 x \% \text { Carbohydrate })+(9 x \% \text { Fat })+(4 x \% \text { Protein })
$$

\subsubsection{Determination of Vitamin $\mathbf{C}$}

About $2 \mathrm{~g}$ of sample is weighed and prepared. $20 \mathrm{ml}$ aliquot of the sample solution was pipetted into a $250 \mathrm{ml}$ conical flask and about $80 \mathrm{ml}$ of distilled water added. $1 \mathrm{ml}$ iodine solution was added. Sample is then titrated with $0.001 \mathrm{M}$ iodine solution. The endpoint of the titration is identified as the first permanent trace of a dark blueblack colour due to the starch-iodine complex using $1 \%$ starch as an indicator. Repetitions was carried out until results are obtained (titre $=$ within $0.1 \mathrm{ml})(\mathrm{AOAC}, 2004)$.

Ascorbic acid content $(\mathrm{mg} / 100 \mathrm{~g})=\frac{\text { Titre } x \text { molarity of titrant } x 176.12}{\text { Weight of sample }} \times 100$

Where $=$ Constant Value $=176.12=$ Molecular Weight $(176.12 \mathrm{~g})=$ Molecular Weight of Ascorbic Acid (Vitamin C). (Pathy and Krishna, 2018) 


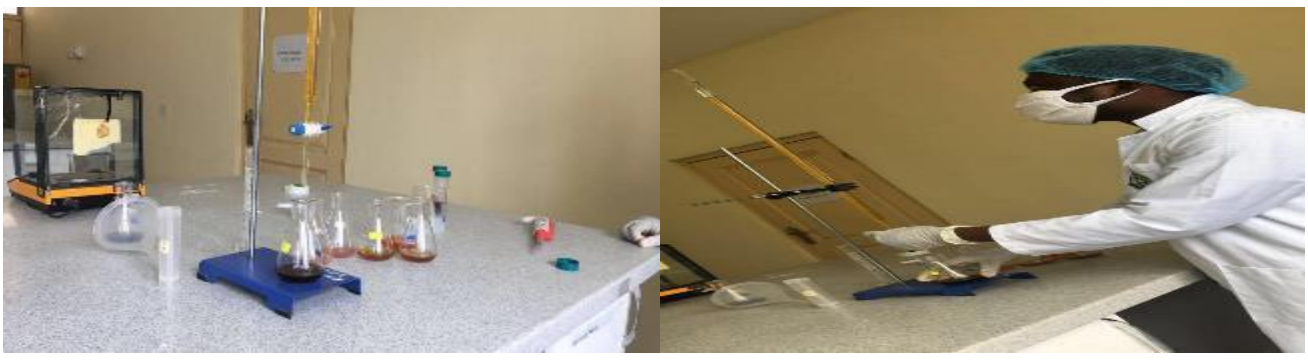

Plate 4: The titration stage during the Vitamin $\mathrm{C}$ determination.

\subsubsection{Physico-Chemical Properties}

\subsection{1 pH Determination}

All $\mathrm{pH}$ measurements were done in triplicates. The $\mathrm{pH}$ meter (Orion 2 tar $\mathrm{pH}$ meter) was calibrated using the manual guide. The electrode was removed and rinsed with distilled water. It was then placed into the samples and tested. The $\mathrm{pH}$ readings were then read thrice for each sample from the electronic display. (AOAC, 2004).

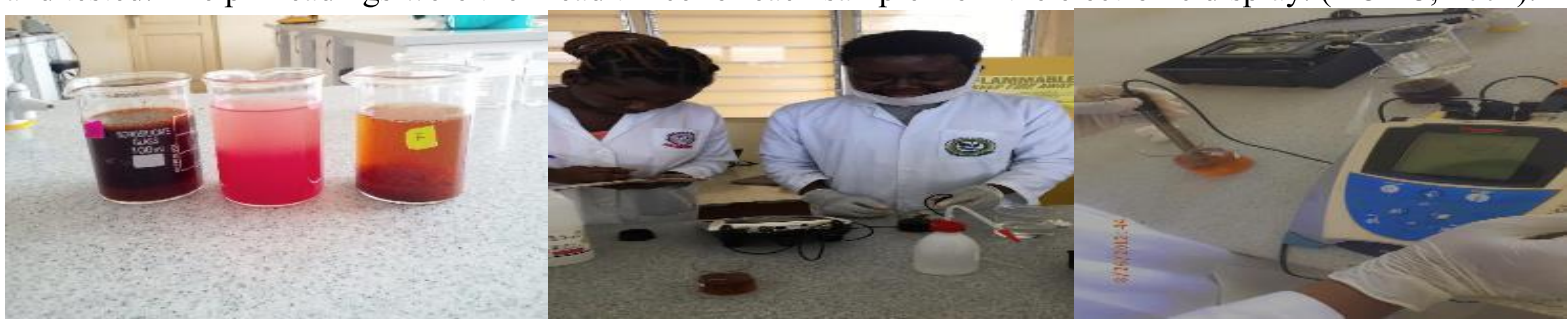

Plate 5: Determination of the $\mathrm{pH}$ using a digital $\mathrm{pH}$ meter.

\subsubsection{Total Soluble Solids Determination}

A table top refractometer (HI- 96801, 0-85\% Brix) was used to determine the ${ }^{\circ}$ Brix of the samples. The refractometer was first calibrated with distilled water. One to two drops of the dried and dissolved tomato samples and samples of the air-dried tomato sample was placed on the prism sensor and was allowed to read. The brix level in degrees was recorded from the electronic display when viewed. One ${ }^{\circ} \mathrm{Brix}\left(1^{\circ} \mathrm{Bx}\right)$ is equivalent to $1 \%$. The prism surface was then cleaned after every sample reading. Triplicate measurements were taken for each sample. (AOAC, 2004).

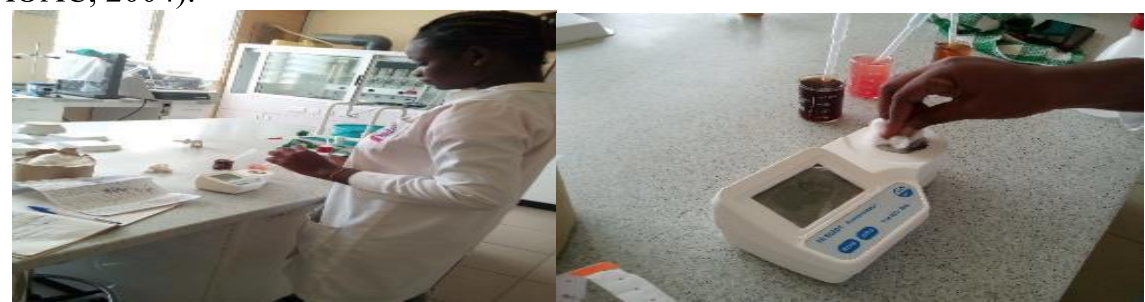

Plate 6: Determination of the Total Soluble Solids

\subsubsection{Statistical Analysis}

The data collected during the laboratory experiments was presented as standard deviation of three independent replications. The statistical significance was generated by subjecting the results of the analysis to t-test (nonparametric tests) to compare the mean and standard deviation using Graph Pad prism version 5 software for the proximate composition of the tomato samples.

\subsection{Results and Discussion}

Freeze-drying and oven drying of tomatoes may affect its quality, whether nutritional, physico-chemical or antioxidant. Since, these are all important determiners in both consumer acceptability and shelf-stability of tomatoes, it is important to study the impact of these drying methods on these quality parameters. The quality parameters studied in this paper includes proximate, mineral, $\mathrm{pH}$, TSS and Vitamin C content. 
3. 1.0 Physicochemical Analysis on different treatment on processed tomato (Lycopersicon esculentum Mill) Table 2: Physicochemical Analysis on different treatment on processed tomato (Lycopersicon esculentum Mill)

\begin{tabular}{llll}
\hline Sample treatment/ Parameters & C & O & F \\
\hline${ }_{\mathrm{PH}} \pm$ SD & $4.54 \pm 0.02^{\mathrm{a}}$ & $3.92 \pm 0.02^{\mathrm{b}}$ & $4.20 \pm 0.02^{\mathrm{c}}$ \\
T.S.S ${ }^{\circ}$ Brix & $1.20 \pm 0.00^{\mathrm{a}}$ & $2.31 \pm 0.01^{\mathrm{b}}$ & $1.81 \pm 0.01^{\mathrm{c}}$ \\
\hline
\end{tabular}

T.S. $S=$ Total soluble solids, ${ }_{p} H=$ Hydrogen ions concentration. Each value is presented as mean \pm standard deviation. Means within a row with the same letter superscript is not significantly different ( $P>0.05$ Tukey's test) whereas those with different superscripts are significantly different $=(P<0.05$ Tukey's test $)$. C $=C o n t r o l$ treatment $O=O v e n$ dry treatment $F=$ Freeze dry treatment

\subsection{1 pH}

The $\mathrm{pH}$ of tomato powder is an important parameter associated with microbial quality as well as its sensory attributes such as the intensity of its flavour. In our study, we found that the $\mathrm{pH}$ of the tomato samples analyzed differed significantly from each other $(\mathrm{p}<0.05)$. From table 2 , the mean value of the $\mathrm{pH}$ for samples $\mathrm{O}, \mathrm{F}$ and $\mathrm{C}$ were $3.92 \pm 0.02,4.20 \pm 0.02$ and $4.54 \pm 0.02$ respectively. Both $\mathrm{O}$ and $\mathrm{F}$ samples, had a lower $\mathrm{pH}$ than the control. This is in disagreement with prior studies, where drying rather increased the $\mathrm{pH}$, thus making the sample less acidic. However, our study indicates that tomato powders were more acidic than the fresh tomato. Though, most of the acids are soluble in water, it seems high amounts of the acid component of the tomato was retained per unit gram, during the drying processing. Albeit, noticing a more dramatic decrease with the O sample shows that, it may be the most shelf-stable and flavorful among the two dried samples. Aside this, the $\mathrm{pH}$ of both samples $\mathrm{O}$ and $\mathrm{F}$ were slightly outside the range $4.28-4.36$ reported for dried tomatoes (Hussein et al., 2015). However, according to Campos et al., (2006), $\mathrm{pH}$ of 4.5 or below is desirable in tomato, especially if it is intended for use in industry. Low $\mathrm{pH}$ is a contributing factor to a low rate of existence and development of spoilage microorganisms (Ullah, 2009). Hence, the oven drying method is likely to produce a more shelf-stable powder than the freeze-drying method.

\subsubsection{TSS Brix}

The TSS Brix level is an objective measure of the dissolved solids in the tomato fruits (Beckles, 2012). However, it relates to a subjective criterion for measuring fruit and vegetable quality such as flavour and sweetness. The TSS of the tomato samples in our study, varied significantly from each other $(\mathrm{p}<0.05)$. The highest Brix was $2.31 \pm 0.01$ for $\mathrm{O}$ sample and lowest for $\mathrm{C}$ sample with $1.20 \pm 0.00$ Brix respectively. The $\mathrm{F}$ sample falls within this range with, $1.81 \pm 0.0$ Brix. This disagrees with Aboagye-Nuamah (2018), who found that drying did not influence the TSS of tomato. Some previous studies have indicated certain factors that influence the TSS of tomato and these include season of cultivation, differences in cultivar, ripening stage, and maturity stage of the tomato fruit (Mabengwa, (2013; Dumas et al., 2015). In this study, both oven and freezedrying methods increased the Brix of tomato. Though, the Brix of the O sample was significantly higher than the F sample. Higher Brix is also indicative of a better taste and suitability for paste production (Beckles, 2012). However, even the highest Brix in our study (Table 2), was far below the standard for tomato that is suitable as an industrial ingredient, $4.8-8.8 \%$.

Table 3: Proximate Analysis on different treatment on processed tomato (Lycopersicon esculentum Mill)

\begin{tabular}{llll}
\hline Sample Treatment / Parameters & C & O & F \\
\hline Moisture (\%) \pm SD & $92.00 \pm 0.06^{\mathrm{a}}$ & $15.50 \pm 0.01^{\mathrm{c}}$ & $10.50 \pm 0.01^{\mathrm{b}}$ \\
Fat (\%) \pm SD & $1.03 \pm 0.03^{\mathrm{a}}$ & $2.03 \pm 0.03^{\mathrm{b}}$ & $2.05 \pm 0.04^{\mathrm{b}}$ \\
Ash (\%) \pm SD & $0.50 \pm 0.01^{\mathrm{a}}$ & $0.52 \pm 0.02^{\mathrm{a}}$ & $1.50 \pm 0.01^{\mathrm{b}}$ \\
Crude Fibre (\%) \pm SD & $0.41 \pm 0.01^{\mathrm{a}}$ & $0.51 \pm 0.01^{\mathrm{b}}$ & $0.53 \pm 0.01^{\mathrm{b}}$ \\
Crude Protein (\%) \pm SD & $2.71 \pm 0.01^{\mathrm{a}}$ & $2.40 \pm 0.01^{\mathrm{b}}$ & $4.07 \pm 0.06^{\mathrm{c}}$ \\
Carbohydrate (\%) \pm SD & $3.39 \pm 0.01^{\mathrm{a}}$ & $76.30 \pm 0.01^{\mathrm{b}}$ & $84.1 \pm 0.57^{\mathrm{c}}$ \\
\hline
\end{tabular}

Each value is presented as mean \pm standard deviation. Means within a row with the same letter superscript is not significantly different ( $P>0.05$ Tukey's test) whereas those with different superscripts are significantly different $(P<0.05$ Tukey's test). $C=$ Control treatment $O=O$ ven dry treatment $F=$ Freeze dry treatment.

\subsubsection{Proximate Analysis on Different Treatment on Processed Tomato (Lycopersicon esculentum Mill) 3.2.1 Moisture Content}

One of the major impacts of drying is to lower moisture content, and with it reduce bulk and hence aid transport and packaging. Since, water is the medium for both enzymatic degradation and microbial spoilage, lower moisture also improves shelf-stability of the product. There was a significant difference $(\mathrm{p}<0.05)$ among the moisture content of the samples. The $\mathrm{C}$ sample had the highest moisture content with $92.00 \pm 0.06$. This falls within the range that Aboagye-Nuamah et al., (2018), reported for six tomato varieties found in Ghana. The dried samples showed lower moisture content indicative of effectiveness, since, an immense reduction in moisture content is expected after a fresh product is dried. The $\mathrm{O}$ sample had a slightly higher moisture content $15.50 \pm 0.01$ compared to that of the $\mathrm{F}$ sample which have $10.50 \pm 0.01$. Hence, the freeze drying method was a 
more effective system of dehydration as compared to the oven-drying method in this study. This agrees with Mozumder et al., 2012 and Surendar et al., 2018. Decreasing the moisture contents of a product reduces its water activity. This also suggest the F sample would be a more shelf stable tomato powder as compared to the ovendried sample (Damodaran et al., 2008).

\subsubsection{Crude Fat}

For crude fat content, there was a significant difference between the control sample $(\mathrm{C})$ and the dried samples $(\mathrm{O}$ and F), but there was no significant difference between the dried samples. The crude fat mean values ranged from $1.03 \pm 0.03$ for the $\mathrm{C}$ sample; $2.03 \pm 0.03$ for the $\mathrm{O}$ sample and $2.05 \pm 0.04$ for $\mathrm{F}$ sample. This may be as a result of oxidation of the fats at higher temperatures and long drying durations. The low crude fat content of all samples agrees with the fact that tomato fruit is a low-fat fruit. However, the fat content of all the samples were much higher than previously reported $(0.19-0.51 \%)$ by Badejo et al., $(2016)$ and lower than reported $(3.9 \%)$ by Surendar et al., (2018). Mozumder et al, (2012) and Surendar et al., (2018) have both reported that, high fat content is connected with low moisture. However, in this work the freeze-dried sample had both a higher moisture and fat content than the oven dried sample. Since freeze-drying uses a much lower temperature than oven drying, it was able to retain a higher content of moisture and fat compared to oven drying (Table 3). Fat influences the flavour of product, however, though higher in $\mathrm{F}$ than $\mathrm{O}$, there was no significant difference between the two dry samples in relation to fat content.

\subsubsection{Crude Ash}

Crude ash is a measure to indicate the total amount of minerals present within a food. There was no significant difference $(p \leq 0.05)$ in the ash value contents of the $C$ sample with $0.50 \pm 0.01$ and the $O$ sample with $0.52 \pm 0.02$. However, the $\mathrm{F}$ sample had an ash content of $1.50 \pm 0.01$ which is significantly different from the others. Freezedried samples have been reported to have higher ash content to other drying technologies (Morris. 2004). This means that it may have been able to retain the integrity of most mineral component being a low heat drying technology. Therefore, aside difference in inputs (Oke et al., 2005), drying technology seem to contribute to the mineral content of dried tomato powders.

\subsubsection{Crude Fiber}

From the results shown, there was a significant difference between the crude fiber content of the control sample, $\mathrm{C}, 0.41 \pm 0.01$ and the dried samples, $0.53 \pm 0.01$ for $\mathrm{F}$ and $0.51 \pm 0.01$ for the O. However, there was no significant difference $(\mathrm{p} \leq 0.05)$ between the dried samples. High fiber content is nutritionally beneficial since it promotes health and aids digestion of food.

\subsubsection{Crude Protein}

The lowest protein content was $2.40 \pm 0.01$ recorded in the $\mathrm{O}$ sample whilst the highest fiber content being $4.07 \pm 0.06 \%$ recorded in the $F$ sample. The $C$ sample which also recorded $2.71 \pm 0.01 \%$. There was a significant difference $(\mathrm{p} \leq 0.05)$ in the mean values of all the three tomato samples. The difference in crude protein contents could be attributed to high rate of degradation for the oven dried sample. Protein is heat labile and heat an intensive heat procedure such as found in the oven drying method is likely to lead to a faster rate of protein breakdown. However, there was an overall a high protein content from all samples, as compared report of some with previous researches $(0.31-0.51 \%)$ (Badejo et al., 2016). This may be due to differences in cultivar and also environmental conditions during cultivation.

\subsubsection{Total Carbohydrate}

The $\mathrm{C}$ sample had the lowest carbohydrate content and the F tomato sample had the highest; with $3.39 \pm 0.01 \%$ and $84.1 \pm 0.57 \%$, respectively. There were significant differences observed in carbohydrate contents of all the tomato samples $(\mathrm{p}<0.05)$. The $\mathrm{O}$ sample also recorded $76.30 \pm 0.01 \%$ respectively which falls between the ranges. High fiber and moisture content in the fresh tomato (control) sample could have contributed to the low carbohydrate content of the control sample. However, there was a high carbohydrate content recorded in the dry samples. As was reported by Onuegbu et al., (2013) that there is lower total carbohydrate content $(0.43 \%)$ in control (fresh) samples than oven dried sample at $60^{\circ} \mathrm{C}$.

Table 4: Antioxidant activity on different treatment on processed tomato (Lycopersicon esculentum Mill)

\begin{tabular}{llll}
\hline Sample Treatment/ Parameters & $\mathbf{C}$ & $\mathbf{O}$ & $\mathbf{F}$ \\
\hline Vitamin C $(\mathrm{mg} / 100 \mathrm{~g}) \pm \mathrm{SD}$ & $28.00 \pm 0.01^{\mathrm{a}}$ & $19.40 \pm 0.01^{\mathrm{b}}$ & $22.80 \pm 0.05^{\mathrm{c}}$ \\
\hline Each value is presented as mean \pm standard deviation. Means within a row with the same letter superscript is \\
not significantly different $(P>0.05$ Tukey's test $)$ whereas those with different superscripts are significantly \\
different $(P<0.05$ Tukey's test $) . C=$ Control treatment $O=$ Oven dry treatment $F=$ Freeze dry treatment.
\end{tabular}

\subsubsection{Antioxidant Activity on Different Treatment on Processed Tomato (Lycopersicon esculentum Mill) 3.3.1 Vitamin C}

Vitamin $\mathrm{C}$ content of tomato is important because of its anti-oxidative characteristics. The result showed that there was significant $(\mathrm{p} \leq 0.05)$ difference in vitamin $\mathrm{C}$ contents between the dried and control samples. The vitamin $\mathrm{C}$ contents of $\mathrm{C}, \mathrm{O}$, and $\mathrm{F}$ samples were $28.00 \pm 0.01 \mathrm{mg} / 100 \mathrm{~g} ; 19.40 \pm 0.01 \mathrm{mg} / 100 \mathrm{~g}$ and $22.80 \pm 0.05$ 
$\mathrm{mg} / 100 \mathrm{~g}$ respectively. The ascorbic acid (vitamin $\mathrm{C}$ ) contents of the dried samples are less than that of the control, that is, the fresh samples. The variation may be due to leaching of the vitamin $\mathrm{C}$ because it is water soluble. Also, the $\mathrm{O}$ sample having less vitamin $\mathrm{C}$, than the $\mathrm{F}$ sample, may be due to oxidative decomposition, owing to its higher temperature requirement (Ratti, 2001). This is in agreement with the works of Famurewa (2010), who reported that drying of vegetable leads to a lowered vitamin C content. Their reports added that more severe drying conditions leads to higher losses of vitamin C. Other reports have also indicated that drying tomato at high temperatures can lower its vitamin C content (Chang et al. 2006; Toor and Savage, 2006).

\subsection{Conclusion}

The study was conducted to analyze the effect of a common drying method (Oven drying) and a modern drying method (Freeze-drying) and compare their effects on the proximate composition and other quality parameters to the fresh tomato. The results indicated that both drying methods had great influence on the proximate composition, vitamin $\mathrm{C}$ content, the brix and $\mathrm{pH}$ of tomatoes. Both methods used, significantly lowered the moisture and increased the carbohydrate content of the tomato, which is to be expected for any effective method of dehydration or drying technology. They both increased the fat and fiber content of the tomato. The lower $\mathrm{pH}$ and higher brix of the oven dried sample compared to the freeze-dried sample, may give it a better sensorial acceptability. The freeze-dried sample also had a higher protein and mineral contents, as well as a lowered loss in vitamin $\mathrm{C}$ content and lower moisture content as compared to the oven-dried sample; possibly making it a more shelf-stable, nutritive and health beneficial option to consumers. Either can be easily incorporated into soups and stews and as bases for other tomato products.

\section{References}

Kader A.A. (1992). Postharvest technology of horticultural crops. (2nd Ed), Univ. California, USA, pp 54-55.

Aboagye-Nuamah F., Hussein Y. A. and A. Ackun (2018), Biochemical properties of six varieties of tomato from Brong Ahafo Region of Ghana as influenced by the ripening condition and drying. African Journal of Food and Agricultural Nutritional Development.18(1): 13095-13109.

A.O.A.C. (2004). Official Methods of Analysis. In Association of Official Analytical Chemists,

Badejo, A. A., Adebowale, A. P., Enujiugha, V. N. (2016). Changes in Nutrient Composition, Antioxidant Properties and Enzyme Activities of Snake Tomato (Trichosanthes cucumerina) during ripening. Journal of Nutrition and Food Science,21 (2): 90 - 96.

Bashir N., Bhat M. A., Dar B. N, and M. A. Shah (2014), Effect of different drying methods on the quality of tomatoes. Advances in Food Science, 36:(2): 65-69

Beckles D. M. (2012), Factors affecting the postharvest soluble solids and sugar content of tomato (Solanum lycopersicum L.) fruit. Postharvest Biology and Technology. 63: 129 - 140.

Brasseaux, Ryan A, Carl A. (2014) Jambalaya, In Edge, John T (ed.) the New Encyclopedia of Southern Culture: Volume 7: Foodways. University of North Carolina Press. p.188

Campos C. A. B., Fernandes P. D., Gheyi H. R., Blanco F. F., Goncalves C. B. and S. A. F. Campos Yield and fruit quality of industrial tomato under saline irrigation. Sci. Agric., 2006; 2:63-69.

Chang C-H, Lin H-Y, Chang C-Y, Liu Y-C. 2006. Comparison on antioxidant properties of fresh, freeze-dried and hot-air-dried tomatoes. J. Food Eng 77:478-485.

Corzo O., N. Bracho A. Pereira and A. Vasquez. 2008. Weibull distribution for modeling air drying of coroba slices. LWT-Food Sci. Technol. 41(6): 1108-1115.

Damodaran S, Amino acids, peptides and proteins. In S. Damodaram, Parkin, K L and Fennema, OR (2008). Fennema's Food Chemistry 4 Ed. Bocath Raton, CRC press pp 217 -330.

Dumas, Y., Dadomo, M., Lucca, G. D. and Grolier, P. (2003). Effect of environmental factors and agricultural technologies on antioxidant content of tomatoes. Journal of the Science of Food and Agriculture. 83: 369383.

Durance, T. D., \& Wang, J. H. (2002). Energy consumption, density and rehydration rate of vacuum microwaveand hot-air convection dehydrated tomatoes. J of Food Sci. 67(6), 2212-2216. DOI:10.1111/j.1365-2621. 2002.tb 09529.x.

Ellis, W.O., Olympio, N.S., Mensah, E. P., Adu-Amankwa, A. and Tetteh, Y. (1998). Postharvest problems of tomato production in Ghana - Field studies of some selected major growing areas in Ghana. Journal of the Ghana science association volume 1, number 1, July (1998FAO) pp. 55-59. ISSN: 0855-3823.

Ertekin, C. \&Yaldiz, O. (2004). Drying of eggplant and selection of a suitable thin layer drying model. Journal of Food Eng. 63(3), 349-359.DOI: http://dx.doi.org/10.1016/j.jfoodeng.2003.08.007.

Famurewa JAV. 2010. Effect of drying methods on Chemical Composition of Red Bell Pepper (Capsicum annum). Journal of Applied Tropical Agriculture.

FAO, (2001). FAO Bulletin of Statistics. Food and Agriculture Organization of the United Nations (FAO), 2: 85

FAO, Food and Agriculture Organization (2010). FAOSTAT. http://faostat.fao.org. 
Mabengwa, M. (2013). Growth responses of tomato (Lycopersicon esculentum Mill) to different growing media under greenhouse and field conditions. MSc. Thesis (Published), University of Zambia. pp. 122

Ministry of Food and Agriculture (MoFA), Statistics, Research and Information Directorate (SRID) (MOFA, SRID) (2013).

Ministry of Food and Agriculture (MoFA), Statistics, Research and Information Directorate (SRID) (MOFA, SRID) (2019).

Morgan, L. and Lennard, S. (2000), Hydroponic capsicum production. Casper Publications Pty Ltd. Australia.

Morris A, Barnett A, Burrows O, (2004), Effect of processing on nutrient content of foods. Cajanus, 37(3): 160164

Mozumder NHMR, Rahman MA, Kamal MS, Mustafa AKM and Rahman MS, Effects of Pre- drying chemical treatments on quality of cabinet dried tomato powder. J. Env. Sci. \& Nat. Res., 2014, 5(1): $253-265$

Naika, S., Jeude, J. L., Goffau, M., Hilmi, M. and Dam, B. (2005). Cultivation of tomato. Agromisa Foundation and CTA, Wageningen. Pp 6-64

Norman, J. C. (1992). Tropical Vegetable Production. Macmillan press pp 52-67

Oke M., A. Taehyun, Schofield A. and P. Gopinadhan (2005). Effects of Phosphorus Fertilizer Supplementation on Processing Quality and Functional Food Ingredients in Tomato. Journal of agricultural and food chemistry. 53. 1531-8. 10.1021/jf0402476.

Okos, R.M., Narsimhan, G., Singh, R.K. and Weitnauer, A.C. 1992. Food Dehydration. In: Heldman, D.R.; Lund, D. B. (Edt): Handbook of Food Engineering. New York: Marcel Dekker, Inc. pp. 437-562.

Onuegbu N. C., Kalu H, Ihediohanma NC, Bede NE, (2013) Effects of Different Pretreatments on the Nutritional and Sensory Qualities of Tomato (Lycopersicum esculantum) Powder. Int. J. of Life

Owureku-Asare M, Ambrose K, Oduro I, Tortoe C, Saalia FK. Consumer knowledge, preference, and perceived quality of dried tomatoes in Ghana. Food Sci. Nutr.2017;5:617-624.https://doi.org/10.1002/fsn3.439

Owusu John, Haile Ma, Zhenbin Wang and Agnes Amissah (2012). Effect of Drying. Methods on Physicochemical Properties of Pre-treated Tomato (Lycopersicon esculentum mill.) Slices. Croatian Journal of Food Technology, Biotechnology and Nutrition 7 (1-2): 106-111.

Pathy, Krishna Sarma, (2018). Process for Preparation of Vitamin C and Method for Determination of Vitamin C in Tablets. Surgery and Case Studies: Open Access Journal, 1(3) 52-65

Peralta, I. E. and Spooner, D. M. (2007). History, Origin and Early Cultivation of Tomato (Solanaceae). In: Razdan, M. K. And Mattoo, A. K. Editors. Genetic Improvement of Solanaceous Crops, Vol. 2. Enfield, USA: Science Publishers. P. 1-27.

Ratti C. (2001), Hot-air and freeze-drying of high-value foods: a review. Journal of food engineering. 49: 311 319.

Slimestad, R. \&Verheul, M. (2009). Review of flavonoids and other phenolics from fruits of different tomato (Lycopersicon esculentum Mill.) cultivars. J of the Sci. of Food and Agri. 89(8), 1255-1270. DOI: $10.1002 /$ jsfa.3605.

Surendar J., Shere D. M. and Shere P. D. (2018). Effect of drying on quality characteristics of dried tomato powder. Journal of Pharmacognosy and Phytochemistry. 7(2): 2690-2694

Toor R and Savage G. 2006. Effect of semi-drying on the antioxidant components of tomatoes. Food Chem. 94:90-97.

Veillet, S., Busch, J., \& Savage, G. (2009). Acceptability and antioxidant properties of a semi-dried and smoked tomato product. J of Food Agri. \& Env., 7(2), 70-75.

Ullah, J. (2009). Storage of fresh tomatoes to determine the level of calcium chloride coating and optimum temperature for extending shelf life. A post Doctorate Fellowship Report submitted to Professor Athapol Athapol Noomhorm.

Wang, Y. X., Mackenzie, B., Tsukaguchi, H., Weremowicz, S., Morton, C. C., \& Hediger, M. A. (2000). Human vitamin C (L-ascorbic acid) transporter SVCT1. Biochemical and Biophysical Research Communications, 267(2), 488-494.

Xianquan, S., Shi, J., Kakuda, Y., \& Yueming, J. (2005). Stability of lycopene during food processing and storage. J of Med. Food, 8(4), 413-422. DOI:10.1089/jmf.2005.8.413 